\title{
RYTŲ IR PIETRYČIŲ AZIJOS GEROVÉS VALSTYBIŲ MODELIŲ SPECIFIKA BEI RAIDOS PROBLEMATIKA
}

\author{
Adomas Vincas Rakšnys, Giedrè Svirbutaitė-Krutkienė, Arvydas Guogis \\ Kazimiero Simonavičiaus universitetas, Vilniaus kolegija, \\ Mykolo Romerio universitetas (Lietuva)
}

\begin{abstract}
Anotacija
Šio straipsnio tikslas - nustatyti ir išanalizuoti Rytų bei Pietryčių Azijos gerovès valstybės modelius ir jų bruožus. Tuo tikslu nagrinèti Rytų ir Pietryčių Azijos gerovès valstybės modeliai, jų bruožai. Aprašyti skirtingi bandymai apibrež̌ti Rytų ir Pietryčių Azijos gerovès valstybės sistemas, pateiktas palyginimas su G. Esping-Andersen'o trijų modelių tipologija. Išskirti Rytų ir Pietryčių Azijos gerovès valstybėms būdingi bruožai, tokie taip konfucianizmo įtaka, produktyvizmas, šeimos reikšmė socialinès rūpybos srityje, analizuota politikos bei ekonomikos įtaka gerovės valstybės raidai. Taikyti mokslinès literatūros analizès, ekspertinio vertinimo, aprašomasis analitinis, sintezès ir lyginamosios analizès metodai.

PAGRINDINIAI ŽODŽIAI: gerovès valstybė, gerovès modelis, vystymosi gerovė, Rytų ir Pietryčių Azija.
\end{abstract}

\begin{abstract}
The aim of this article is to identify and analyse welfare state models and their features in East and Southeast Asia. With this in mind, the article examines welfare state models in East and Southeast Asia and their characteristics. Different attempts to define the welfare state systems of East and Southeast Asia are provided, as well as a comparison with G. Esping-Andersen's typology of three models. The characteristics of the welfare states of East and Southeast Asia are distinguished, such as the influence of Confucianism, productivity, the role of the family in the field of social welfare, and the influence of politics and the economy on the development of the welfare state. The article uses methods of analysis of scientific literature, expert evaluation, synthesis, descriptive analysis and comparative analysis.
\end{abstract}

KEY WORDS: welfare state, welfare model, developmental welfare, East and Southeast Asia.

DOI: http://dx.doi.org/10.15181/tbb.v87i2.2317

\section{Ivadas}

1980-ujų metų pabaigoje - 1990-ụjų metų pradžioje Rytų Azijos valstybės pritraukė mokslininkų ir praktikų dėmesi savo ypač sparčiu ekonomikos augimu, kuris pagrịstas valstybės pasiekta autonomija nuo privačių interesų grupių, jos gebejjimu mobilizuoti ribotus ekonominius išteklius ir vykdant savo vystymosi strategijas vadovauti privačioms įmonėms (Park, 2007). Priešingai nei ekonomikos augimas, ilgą laiką Rytų ir Pietryčių Azijos valstybėse socialinė gerovė buvo visiškai pamiršta. Ekonominė plètra buvo pagrindinis Rytų ir Pietryčių Azijos valstybių tikslas, o gerovès valstybès programos ar pati socialinè politika - šio tikslo siekimo ịrankis, neretai veikęs tarsi ekonomikos politikų periferijos šešèlyje. Tačiau 
Adomas Vincas Rakšnys, Giedrè Svirbutaitè-Krutkienė, Arvydas Guogis

1990 metais danų sociologo G. Esping-Andersen'o pristatyta gerovès modelių klasifikacija sukèlė susidomèjimą ir dẻl Rytų / Pietryčių Azijos gerovės valstybių programų bei jų klasifikacijos.

Ankstesnès studijos ir mokslo darbai Rytų Azijos gerovès valstybes suprato bei nagrinejjo išskirtinai tik kaip ekonominį veiksnį. 1997 metais visą Aziją ištikusi ekonominè krize, jos poveikis paskatino mokslininkus ir praktikus diskutuoti, kaip Rytų Azijos valstybėms pavyksta šią sparčią socialinę-ekonominę krizę ịveikti, ir kaip ši patirtis perkelta / neperkelta ị jų gerovès programas. Mokslininkus domino ir Rytų Azijos fenomenas: kaip įmanoma pasiekti aukštą valstybės gerovès lygị ir ekonominį augimą, kai socialinès išlaidos nedidelès. Ilgainiui šis fenomenas vadintas skirtingai: Rytu Azijos stebuklas, Rytu Azijos tigrai, Rytu Azijos paslaptis ir kt.

Rytų ir Pietryčių Azijos gerovės modeliai, jų kūrimas neišvengiamai patyrè ịvairių iššūkių - ekonomikos restruktūrizavimo, spartaus visuomenès senejjimo, kitų demografinių pokyčių, mažinamo pensinio amžiaus, mažèjančios paramos šeimoms ir t. t. (Choi, 2007). Visa tai sukẻlè nemažai socialinių problemų ir privertè rimtai permąstyti ne tik socialinès apsaugos sistemas, bet ir patị gerovès valdymo modelį. Todèl pradèta sparčiai kurti socialinès politikos ir jos valdymo modelį, vykdyti reformas.

Nagrinėdami Rytų Azijos gerovès režimus, dalis autorių savo darbuose perèmé G. Esping-Andersen'o gerovès režimų metodologiją, tuo tarpu kiti buvo ịsitikinę, kad Rytų ir Pietryčių Azijos regiono gerovès režimai sudaro paskirą, G. EspingAndersen'o tipologiją išplečiantị modelị. Atsižvelgus ị tai formuluota mokslinè problema - ar egzistuoja išskirtinis Rytų ir Pietryčių Azijos valstybėms būdingas gerovès valstybès modelis? Šio straipsnio tikslas - nustatyti ir išanalizuoti Rytų bei Pietryčių Azijos gerovès valstybès modelius ir jų bruožus. Tikslui pasiekti iškelti uždaviniai: 1) apžvelgti Rytų ir Pietryčiu Azijos gerovès valstybės modelius, jų raidą; 2) išskirti Rytų ir Pietryčių Azijos gerovès valstybèms būdingus bruožus.

Bendroji darbo metodologija ir taikyti metodai. Šiuo apžvalginio tipo straipsniu siekiama mokslinio pažinimo tikslų, pristatant besiformuojantị Rytų ir Pietryčių Azijos gerovès valstybès modelị fenomenologiniu būdu - atskleidžiant jị kaip reiškinị su ,idealiam modeliavimui“ būdingais svarbiausiais elementais bei jų tarpusavio ryšiais, remiantis gausia duoto reiškinio moksline literatūra anglų kalba, taikant aprašomajị analitinị metodą, ekspertinį vertinimą, sintezę ir palyginamajj metodą. 
RYTŲ IR PIETRYČIŲ AZIJOS GEROVĖS VALSTYBIŲ MODELIŲ SPECIFIKA...

\section{Rytų ir Pietryčių Azijos gerovės valstybės modeliai, jų raida}

Nagrinèjant gerovès valstybès idèjos raidą mokslinèje literatūroje dažniausia dèmesys sutelkiamas ties Šiaurès Europos valstybėmis, jų socialinės politikos ir viešujų paslaugų teikimo specifika. Švedijos ir kitų socialdemokratų partijų valdomų šalių atvejai dažnai minimi kaip pavyzdiniai. Visgi, atsižvelgiant ị XXI amžiaus ekonominius, socialinius bei kultūrinius iššūkius, būtina vertinti ir kituose geografiniuose, kultūriniuose kontekstuose pasiteisinusius modelius bei gerovès valstybès idèjos igyvendinimo priemones.

Vis dažniau moksliniame diskurse dėmesys kreipiamas ị Rytų Azijos gerovès valstybes, jų modelių specifiką bei igyvendinimo principus. Iki 1990 metų net svarstyta, ar Rytų ir Pietryčių Azijos gerovès valstybių modeliai negalètų būti pritaikyti Vakarų demokratinèse valstybėse (Hort, Kuhnle, 2000), ar Rytų Azijos regione gerovès valstybės idejos jau institucionalizuotos (Kim, Shi, 2013), kokie jų esminiai ekonominiai ir instituciniai skirtumai demokratinių bei autoritarinių politinių sistemų kontekste.

Nors būtina pažymèti, kad mokslininkai dẻl homogeniškų Rytų ir Pietryčių Azijos gerovės valstybės modelių išskyrimo vis dar abejoja, nes tam stokojama empirinių įrodymų (Yang, 2017), dažnai jie vertinami labiau kaip ,idealieji tipai““ (Lin, Chan, 2013). Tokios diskusijos vyksta pabrèžiant, kad Rytų Azijos valstybių reformos galbūt jau juda Europos gerovès valstybių link (Abrahamson, 2017). Kita vertus, Rytų ir Pietryčiu gerovès valstybių perskirstomasis pobūdis silpniau išreikštas nei Vakarų šalių.

C. Y. Yeh'us ir Y. W. Ku' as atliko empirinị tyrimą, kuriuo siekè išsiaiškinti, ar Rytų Azijos gerovès režimai Japonijoje, Pietų Korėjoje ir Taivane skiriasi nuo G. Esping-Andersen'o trijų gerovès valstybių modelių. Tai vienas iš nedaugelio empirinių tyrimų, kuriame buvo 15 kintamujų (vyriausybès socialinès išlaidos, socialinès investicijos, pensijų aprẻptis, lyčių diskriminacija, šeimos parama, darbdavių indèlis ir pan.), be to, atlikta dvidešimties šalių klasterinè analizė (Choi, 2007). Tyrimo rezultatai įrodè, kad Rytų Azijos valstybès G. Esping-Andersen’o modelių neatitinka ir sudaro unikalų ketvirtajj tipą.

Išties Rytų ir Pietryčių Azijos valstybės, nors pasižymi skirtingais bruožais, turi liberaliojo ar konservatyviojo režimų bruožų. Tarkim, H. Kwon'as įžvelgia Rytų Azijos gerovès valstybės panašumų su „bismarkiškuoju“ konservatyviuoju modeliu, kurị taikant siekta palengvinti industrializacijos procesus pasitelkus socialinio draudimo programas, kartu Prūsijoje sumažinti politinę paramą socialistiniams judejjimams (Kwon, 2007). Tokių paskatų būta ir Rytų Azijoje. Tuo tarpu Japonija ir Pietų Korejja yra liberaliojo ir konservatyviojo modelių mišinys. Vis dèlto svarbu 
pabrèžti, kad dèl Pietų Korèjos gerovès režimo nuolat kyla debatų, nes socialinè politika patyrè daugybę pokyčiu, kurie verčia diskutuoti apie jos gerovès modelị.

Apskritai Rytų Azijos gerovès valstybių tipas panašus ị liberalujị su ịvairiomis gerovès valstybės struktūromis (Karim ir kt., 2010). Rytų Azijos valstybių kontekste galima išskirti ir vystymosi gerovès (angl. developmental welfare) modeli, kai siekiant ekonominès pažangos ilgą laiką aukota socialinè ir aplinkosauginè pažanga. Ekonominis vystymasis šiose šalyse tapo savitiksliu, ilgą laiką nesprendžiant socialinių ir aplinkosauginių problemų: ị socialinius reikalus geriausiu atveju atsižvelgta tik tada, jeigu jie vienaip ar kitaip prisidèdavo prie ekonominio augimo.

Produktyvistinio modelio idèją kèlè I. Holliday'us (2000), kurio teigimu, Rytu Azijos atvejị teisingiausia būtų vadinti produktyvistiniu modeliu, kai socialinė politika aukojama dèl ekonominių ir pramoninių tikslų. Gerovės valstybes Rytų Azijos regione nagrinėjęs I. Holliday'us pastebejjo, kad socialinė politika po karo orientuota ị produktyvizmą ir buvo griežtai pavaldi viršesniam politiniam tikslui ekonomikos augimui. Jis pabrèžia, kad socialinès politikos iniciatyvos čia visiškai atsietos nuo bet kokių socialinių teisių ir pilietybès sampratos. Pavyzdžiui, Japonijoje, Pietų Korejjoje ir Taivane universali prieiga prie švietimo suprantama ne kaip gerovès perskirstymo ar socialinès klasės mobilumo išlyginimo mechanizmas, bet kaip žmogiškojo kapitalo plètros priemonè, t. y. iš esmės tai buvo ekonominė investicija. Taigi minimalios socialinès teisès čia susijusios su gamybos veikla, o valstybės-šeimos-rinkos santykiai orientuoti ị ekonominį augimą. I. Holliday'us vèliau pristate išplèstinị produktyvaus gerovés kapitalizmo (angl. productive welfare capitalism) terminą, kaip tiksliausiai apibūdinantị Rytu ir Pietryčių Azijos gerovès valstybių atvejị (Choi, 2007). Produktyvaus gerovės kapitalizmo atveju socialinè politika - tai iš esmès ekonominès politikos išplètimas, ji glaudžiai susijusi su ekonominiais tikslais.

Kaip vieną svarbiausių studijų, padejjusių tašką vẻlesniems Rytų ir Pietryčių Azijos regiono tyrimams, galima išskirti C. Jones'o pristatytą „Konfucijaus gerovès valstybės“ teoriją (sampratą). Remiantis šia Konfucijaus vertybėmis ir kultūra pagrịsta teorija (ypač dẻl šeimos ir giminystès socialinio vaidmens svarbos, kai rūpinimasis socialiai silpnais asmenimis pirmiausia tenka jų šeimoms), stengtasi suprasti ir paaiškinti, kodèl gerovè kuriama pavèluotai ir kodèl tokios mažos socialinès išlaidos (Choi, 2007).

P. Abrahamson'as 2017 m. „Azijos viešosios politikos žurnale“ publikuotame straipsnyje „Rytų Azijos gerovès režimas: pasenęs idealus tipas ar diversifikuota tikrovè" pažymi socialinès politikos priklausomybę nuo ekonominio vystymosi Rytų Azijoje, atkreipia dèmesị ị socialinès globos paslaugas ir konfucianizmo ịtaką socialinei politikai. Autorius detaliai aprašo gerovès vadybą Rytu Azijoje ir daro išvadą, kad nepaisant reikšmingos globos plètros socialinè politika Rytų Azijoje 
RYTŲ IR PIETRYČIŲ AZIJOS GEROVĖS VALSTYBIŲ MODELIŲ SPECIFIKA...

remiasi šeimyniškumo ideologija ir gali būti apibrěžta kaip „,konfucionistinis režimas“ (Abrahamson, 2017).

K. H. Mok'o, S. Kühner'io, N. Yeates straipsnyje „Ivadas - tvarkantis su gerovès lūkesčiais ir socialiniais pokyčiais: politikos atsakymai Azijoje“, kuris pasirodè 2017 m. žurnale „Socialiné politika ir administravimas“, analizuodami socialinès politikos vystymąsi, abejoja dèl Azijos gerovès tipo priskyrimo produktyvistiniam ir pateikia Rytų Azijos regiono vystymosi „,priklausomybès nuo kelio“ variacijas. Išvadose teigiama, kad formuojant atitinkamus gerovès tipus galima aptikti nacionalinių, ekstranacionalinių ir transnacionalinių varomujų jẻgų kompleksiškumą bei jų tarpusavio santykius (Mok ir kt., 2017).

Kai kurių autorių teigimu, Rytų Azijos regioną galima suskirstyti dar ị kelis skirtingus tipus (grupes). Pavyzdžiui, S. E. Hort'as, S. Kuhnle'as teigia, kad viena iš grupių remiasi Vokietijos stiliaus socialinio draudimo programomis, kita - britu kolonializmo palikimu - kaupiamaisiais fondais (Park, 2007). H. Kwon'o teigimu, gerovès valstybès skiriasi tuo, kad vienos yra selektyvios, o kitos - integruotos gerovės valstybės, skiriasi tik gerovės programų apréptis ir tai, kiek valstybės savo gerovės programas kontroliuoja. Pavyzdžiui, 1980 metų pabaigoje Pietų Korejja ir Taivanas, siekdami produktyvumo, integravo savo gerovès programas ị ekonominès plètros strategiją ir demokratizacijos procesus (Park, 2007).

P. Abrahamson'as (2017) Rytų Azijoje skiria šiuos skirtingus gerovès modelius: konservatyvusis režimas (Japonijoje); produktyvistinis vystymosi gerovės režimas (Makao, Hongkonge, Singapūre); universalusis režimas (Kinijoje); „chameleono“ (P. Korèjoje).

I. Holliday'us nustatė tris Rytų Azijos gerovès valstybių tipus: Honkongui būdingą supaprastintą modeli (angl. facilitative), Singapūrui - vystymosi partikuliaristinį (angl. developmental-particularlist), Pietų Korejjai ir Taivanui - vystymosi universaluji (angl. developmental-universalist). Šie tipai skiriasi socialinių teisių institucionalizavimu, perskirstymo rezultatais ir tuo, kiek visuomene dalyvauja socialinès rūpybos sistemoje. Lyginant su kitais tipais, vystymosi universaliajam tipui būdingos kur kas labiau institucionalizuotos socialinès teisès, geriausi perskirstymo rezultatai ir svarbus visuomenès vaidmuo socialinès rūpybos sistemoje. Visiškai priešingomis savybėmis pasižymi supaprastintas modelis, tuo tarpu vystymosi partikuliaristinis modelis atsiduria ties viduriu (Park, Jung, 2007). Remiantis šia klasifikacija, Tailande ir Indonezijoje galime ịžvelgti vystymosi partikuliaristinį tipą, nes šiose valstybėse šeimos vaidmuo užtikrinant gerovę kur kas reikšmingesnis nei valstybės. Malaizija yra savotiškas vystymosi universaliojo ir vystymosi partikuliaristinio tipų mišinys, nes perėmė britams būdingą nacionalinę sveikatos apsaugos bei darbuotojų kaupiamojo fondo programas. 
G. Köhler (2014) gerovès valstybę apibrèžia pasitelkdama jos funkcijas: švietimo, sveikatos apsaugos, socialinės apsaugos, aktyvios darbo rinkos ir šeimos politikos. Autore skiria penkių tipų Azijos gerovės valstybes, kurios, nors ir skirtingos, susijusios su tais pačiais iššūkiais: skurdas, socialinė atskirtis, demografiniai iššūkiai, ekologinès problemos ir pajamų nelygybè. Pirmają grupę sudaro šalys, kurių gerovès valstybès kurtos ekonomikos pagrindu (pramonès politika), siekiant didinti žemès ūkio našumą ir skatinant naujų gamybos šakų plètrą. Kitaip tariant, socialinè politika buvo pavaldi ekonomikos plètrai. Šią grupę sudaro: Japonija, Pietų Korejja, Taivanas, Honkongas, Singapūras ir Malaizija. Kartais ji dar vadinama Azijos tigrais. Praeito amžiaus dešimtojo dešimtmečio pradžioje iškilusi antroji grupè vadinama vystymosi geroves valstybemis, kuriose pabrěžiamas demokratijos formavimasis. Dažnai tai siejama su 1997 metų finansų krize, kuri lèmė reikšmingą BVP mažèjimą, nedarbo didèjimą ir galiausiai iškilusius demokratinius judejjimus, kuriems vadovavo profesinès sajungos, reikalavusios suteikti piliečiams viešąsias gėrybes. Trečiasis - ribojantis - tipas išskirtinai būdingas Kinijai, kur trūksta demokratijos, kartu ryškūs valstybès ịsipareigojimai universalizuojant gerovès valstybės funkcijas. Ketvirtasis tipas apima Pietų Aziją: Bangladešas, Indija, Maldyvai, Nepalas. Nors šiame regione žmonių vystymosi rodikliai (angl. human development indicators) yra vieni žemiausių pasaulyje, tačiau švietimas, sveikatos apsauga, socialinė apsauga ir užimtumas grindžiami socialiniu teisingumu. Mokslininkų teigimu, šis tipas dar gali būti ịvardytas kaip teisemis grįsta vystymosi gerovès valstybė. Paskutiniam, penktajam, tipui priskiriamos regresuojančios valstybės, kuriose stebimas gerovės nuostatų ir teisių nykimas. Puikus tokios valstybės pavyzdys - Šri Lanka, kurioje pakito anksčiau garantuotos universalios teisès ị aprūpinimą maistu ar minimalių pajamų garantija.

Ch. Park'as ir D. Jung'as (2007) nagrinèjo devynių Azijos valstybių (Japonijos, Pietų Korejos, Taivano, Honkongo, Singapūro, Malaizijos, Indonezijos, Tailando ir Filipinų) gerovės valstybes trimis pjūviais: teisės aktų (jų skaičius, prièmimo, veikimo ir kt. laikas), gerovés programų turinio (programų tipas, t. y. ką apima, ką suteikia, koks finansavimas) ir viešujų išlaidų siekiant užtikrinti gerovę aspektais. Autorių nuomone, šių šalių analizė leidžia suprasti, ar tyrimui atrinktos šalys sudaro atskirą, unikalų Azijos gerovès modelị, ar visgi jos yra skirtingų gerovès valstybių režimų „mišiniai“. Atlikus tyrimą nustatyta, kad nepaisant tam tikrų skirtumų visos valstybės turi bendrų bruožų: gerovės programų vaidmuo vykdant ekonomikos plètrą yra tik papildomas; valstybès atlieka reguliatorių vaidmenį, o gerovés paslaugų teikimas yra gana menkas. Naudodamiesi hierarchine analize, autoriai sugrupavo valstybes pagal panašiausius Azijos gerovès valstybių režimus. Pirmajją grupę sudarė Japonija, Pietų Koreja, Taivanas, Tailandas ir Filipinai. Antrą grupę sudarè Honkongas ir Singapūras. Trečiąją grupę - Malaizija ir Indonezija. 
RYTŲ IR PIETRYČIŲ AZIJOS GEROVĖS VALSTYBIŲ MODELIŲ SPECIFIKA...

Verta išskirti 1998 metais publikuotą R. Goodman'o, G. White’o, H. Kwon'o darbą „Rytų Azijos gerovès modelis - gerovès orientalizmas ir valstybé،, kur turbūt geriausiai atskleista Rytų Azijos specifika. Pirmoji dalis skirta palyginamajai Rytų Azijos gerovès analizei santykyje su orientalizmu ir oksidentalizmu. Čia pateikta detali penkių Rytų Azijos visuomenių - Japonijos, Pietų Korejos, Taivano, Honkongo ir Singapūro - gerovès sistemų analizè. Antroje dalyje pateikta istorinè, ekonominė ir politinė penkių Rytų Azijos gerovės sistemų analizė konkrečiose srityse: pensijų, sveikatos draudimo, būsto politikos ir asmeninių socialinių paslaugų. Trečia knygos dalis apima paskirų autorių aprašytus specifinius atvejus, kurie atskleidžia skirtingus požiūrio taškus (Goodman ir kt., 1998).

Pažymėtina, kad nagrinèjant Rytų ir Pietryčių Azijos gerovès valstybes, galima skirti tris esminius raidos etapus, kurie apima laikotarpius iki praeito amžiaus dešimtojo dešimtmečio pradžios, socialinių programų plètrą nuo praeito amžiaus dešimtojo dešimtmečio pradžios, ir šiame amžiuje igyvendinamas socialinès politikos programas (Kim, Shi, 2013).

Y. Choi'aus (2007) teigimu, Vakarų gerovès valstybių režimai, kol igijo dabartinę tvirtesnę formą, patyrè keturis svarbius išbandymus, beje, Rytų ir Pietryčių Azijos valstybèms teko ne visi:

1. Sociodemografiniai: senèjimo procesai, tradicinès šeimos formos žlugimas, nuo XIX a. - modernizacija ir urbanizacija.

2. Politiniai: demokratizacijos procesai ir politinè konkurencija. Vakaru pasaulyje iš esmès nuo 1945 metų demokratija institucionalizuota ir konsoliduota, tuo tarpu socialinès teisès derintos su gerovès valstybių institucijomis. Valstybès turèjo reaguoti ị socialinius ir demografinius pokyčius igyvendindamos ịvairias politikos strategijas. Po įvairių politinių išbandymų naujausios gerovès valstybių programos tapo atsparios galimiems vidaus ir išorès spaudimams.

3. Ekonominiai, įskaitant ekonominius nuosmukius ir krizes, po kurių šalys sukūrẻ grynas kapitalistines ekonomikas. Didžioji depresija ir ekonominès krizès po Antrojo pasaulinio karo, lèmusio didžiulį nedarbą ir skurdą, leido įsitikinti, ar Vakarų šalių gerovės politikos priemonių pakanka, siekiant susidoroti su kilusiais iššūkiais. Rytų Azijos valstybės didžiausius išbandymus patyrė Azijos ekonominės krizės laikotarpiu, kai išryškèjo visi jų trūkumai ir silpnosios vietos. Pavyzdžiui, Pietų Korejoje tapo aišku, kad gerovès valstybe nepajėgi susidoroti su staigiai išaugusiu nedarbu, nes iki tol buvo remiamasi visiško užimtumo prielaida, todèl, smogus krizei, pradèta teikti minimali parama bedarbiams (Kwon, 2007).

4. Lyčių vaidmenų: tolstant nuo tradicinès sistemos, kur vyras buvo šeimos maitintojas, kilo naujų iššūkių. Vis daugiau moterų pradejjus dalyvauti darbo 
rinkoje, susiformavo nauji socialiniai poreikiai, kuriuos vyriausybėms teko tenkinti.

H. Kwon'o nuomone, tik patyrusios ir atlaikiusios šiuos išbandymus, valstybės gali užsitikrinti tvirtesni gerovès valstybių statusą. Tačiau Rytų ir Pietryčių Azija dar nepatyrẻ visų minètų išbandymų. Tarkim, politinė demokratizacija Pietų Korėjoje ar Taivane dar santykinai nauja, demografiniai pokyčiai, tokie kaip senejimas ar namų ūkių transformacijos, daugelyje Rytų Azijos valstybių yra nauji, nors ir sparčiai besivystantys reiškiniai. Neseniai prasidejo ir ekonominiai išbandymai paskutiniajame XX amžiaus dešimtmetyje, kai valstybes išbandė ekonominès recesijos ir krizės. Iki tol Rytu ir Pietryčių Azijos regionas stebino pasauli sparčiu ekonominiu augimu. Taigi kyla klausimas, ar galima Rytų ir Pietryčių Azijos valstybes vertinti kaip gerovès valstybes, kai jos nèra patyrusios visų minètų išbandymų? Galbūt svarbiau kelti klausimą, ne kokios tos valstybès yra dabar, bet kur link jos krypsta?

\section{Rytų ir Pietryčių Azijos gerovès valstybių bruožai, jų specifika}

Kai kurie autoriai pažymi, kad Rytų Azijos gerovès valstybių specifika gali būti aiškinama kultūriniais veiksniais, pirmiausia tvirta konfucianizmo tradicija. Nors konfucianizmas dažnai būdavo aiškinamas kaip ekonominès pažangos trikdis, dabar vis dažniau pripažistama, kad tai yra pozityvi, istorinė, išskirtinumą kurianti jèga, siejama su tvirtais šeimyniniais ryšiais, išsilavinimo poreikiu, paternalizmu, socialine darna, drausme ir darbo etika (Abrahamson, 2017; White, Goodman, 2001; Kim, 2019).

Rytų Azijos gerovès valstybėms būdingi ir kiti bruožai: jos gali būti vertinamos kaip produktyvistinès (angl. productivist), neskiriančios didelių biudžeto lèšu (angl. small spenders), ganètinai statiškos (Abrahamson, 2017). Rytų Azijos gerovės valstybių produktyvizmas dažnai vertinamas skiriant edukacijos, sveikatos sistemos ir šeimos politikos dimensijas (Yang, 2017). C. Y. Yeh'aus ir Y. W. Ku'aso (2021) teigimu, siekdamos greito ekonominio augimo, Rytų Azijos gerovès valstybès privalëjo skirti išteklių ypač produktyvioms veikloms, dèl to valstybinių institucijų vaidmuo teikiant gerovès paslaugas mažintas ir šios funkcijos perduotos nevyriausybinèms organizacijoms bei privačiam sektoriui. Ši tendencija gali būti aiškinama ir neoliberalizmo idejų sklaida. Gerovès valstybės idejjų ịgyvendinimo požiūriu Rytų Azijos patirtis svarbi ir dèl to, kad dèl globalizacijos jas neišvengiamai paveikè ir neoliberalizmo ideologija bei jos paskatintos viešojo valdymo modernizavimo reformos, kaip, pavyzdžiui, Pietų Korejoje (Suh, Kwon, 2014).

T. Miyamoto (2003) yra ịsitikinęs, kad Rytų Azijos gerovès valstybės modelị teisingiausia aiškinti pasitelkus gerovès valstybių formavimosi procesus. Jo nuo- 
RYTŲ IR PIETRYČIŲ AZIJOS GEROVĖS VALSTYBIŲ MODELIŲ SPECIFIKA...

mone, dèl nedidelių socialinių išlaidų Rytų Azijos valstybės laikytinos mažomis gerovès valstybėmis, kadangi vyriausybės ekonomikos plètrai išleidžia daugiau pinigu nei socialinei gerovei. Tad socialinė gerové šiose valstybėse atlieka papildomą ekonominès plètros politikos vaidmenį. Be to, autorius pabrěžia, kad nedidelès Rytų Azijos valstybių socialinès išlaidos nereiškia, jog socialinė politika neveiksminga. Priešingai - Rytų Azijos valstybės puikiai užtikrina privačių gerovę teikiančiu subjektų kontrolę. Pažymètinas šioms valstybėms būdingas fragmentiškumas, kai gerovė užtikrinama privilegijuotoms grupėms, siekiant užsitikrinti ju lojalumą, nors tam tikros programos skirtos ir nuo spartaus ekonomikos vystymosi nukentejusioms grupèms.

M. Izuhara 2013 metais išleistoje „Rytų Azijos socialinès politikos apžvalgoje“, analizuodama socialinę politiką Rytu Azijoje, pažymi, kad ją kartu su kolonializmo palikimu ypač veike konfucianizmas, šeimyniškumas ir produktyvizmas. Šioje monografijoje atsakoma ir ị klausimą, kaip ị rinką orientuotos reformos paveikẻ Rytų Azijos socialinę politiką bei jos sistemas, kokia „vystymosi gerovès“ ir produktyvizmo išliekamoji reikšmè (Izuhara, 2013).

Taigi gerovès valstybės kūrimas Azijoje pagal atitinkamą modelị ypač susijęs su politinio valdymo sistema, visuomenès socialine sandara ir kultūra, kuri suponuoja esminius gerovès valstybės bruožus. Galima pritarti P. Abrahamson'o nuomonei (2017), kad Rytų Azijos valstybėse galima aptikti produktyvistinị ir vystymosi gerovés modelius. Nors jie šiek tiek skiriasi, siekiama, kad socialinè politika prisidetų prie ekonominio vystymosi ir taip kurtųsi mažos bei lanksčios gerovès valstybès. Šiais atvejais gerovès politikos tikslas dvejopas - slopinti potencialios politinès opozicijos galią ir tiesiogiai palaikyti ekonominị vystymąsi, pavyzdžiui, siūlant viešojo švietimo sistemoje puikiai parengtą darbo jègą, tačiau tik pagrindinių šakų darbuotojai buvo ịtraukti ị ribotų įmokų socialinio saugumo sistemas. Tai taikytina tik ankstesniam Japonijos, Pietų Korejos ir Taivano vystymosi laikotarpiui, tačiau šiai pozicijai pritaria ir visa eilè dabartinių gerovès valstybių ekspertų.

Vertinant produktyvistinio modelio raišką, galima pastebèti, kad šiuolaikiniuose Rytų Azijos gerovès valstybių modeliuose vienu metu egzistuoja ir „priklausomybès nuo tako“, ir jo „lūžio“ variantai, tačiau jų produktyvistinė prigimtis susilpnejjusi. Ši tendencija labiau matoma Pietų Korėjoje, kuri sẻkmingai transformavosi ị gerovès valstybę, mažiau - Japonijoje ir Kinijoje (Choi, 2012). Kiti autoriai, pavyzdžiui, W. S. Kim'as, S. J. Shi (2013), pažymi, kad, be konfucianizmo tradicijos, būtina skirti produktyvistinius Rytų Azijos valstybių bruožus, kai socialinė politika orientuota ị produktyvumo didinimą.

Panašios pozicijos laikosi H. Kwon'as (1999), kuris, remdamasis R. Goodman'o ir G. White'o tyrimais, išskyre Rytų Azijos gerovès valstybių stiprybes, kaip svarbų veiksnị pažymėdamas ir ekonominị augimą bei kažkiek ir ị perskirsto- 
mają gerovę orientuotą ideologiją ir praktiką. Tačiau šių gerovės valstybių skiriamų lèšu ir pasitelkiamo personalo sąnaudos nedidelès. Rytų Azijos gerovės valstybės stengiasi kurti tokią gerovės aplinką, kur viešojo sektoriaus taikoma apsauga (angl. safety nets) būtų silpna, taip skatinant darbo ir disciplinos kultūrą.

Šiose valstybėse išnaudojami bendruomeniniai, verslo organizacijų, grupių ir šeimos teikiami privalumai. Pavyzdžiui, Pietų Koreja ir Taivanas po Antrojo pasaulinio karo pasirinko panašią vystymosi kryptị. Šios šalys siekė modernizacijos ir socialinès transformacijos, kurios lẻmè reikšmingą socialinès politikos pažangą. Toks vystymasis neatsiejamas nuo politinès demokratizacijos (Kim, Shi, 2013). Prie šių valstybių būtina priskirti ir Japoniją. Galima pritarti nuomonei, kad šios valstybės yra puikūs vystymosi gerovés modelio pavyzdžiai, kur norimi rezultatai pasiekti valstybès makroekonominio planavimo ir intervencijos priemonèmis, pabrèžiant sparčią industrializaciją ir technologizaciją. Tačiau kai kuriose valstybėse galima matyti autoritariniais bruožais pasižyminčias valdymo sistemas, kuriomis taip pat siekta paskatinti ekonomini augimą, kaip, pavyzdžiui, Kinijoje ar iš dalies autoritariniame Singapūre. Autoritarinès tendencijos buvo būdingos ir Pietų Korèjai, bet maždaug nuo 1987 metų ji pasirinko demokratizacijos kelią (Choi, 2012). Manoma, kad būtent spartus Kinijos valstybès ekonominis augimas reikšmingai paveikè minètų valstybių raidą (Chiavacci, Grano, 2020). Tam linkę pritarti ir kiti autoriai, pavyzdžiui, J. Y. Choi (2012).

Vystymosi gerovès modelio bruožai neatsiejami nuo valstybès institucijų, biurokratinių struktūrų ir spartaus ekonominio augimo. Analizuojant gerovès valstybės politikos reformas, pastebimi Singapūro, Japonijos, Korẻjos ir Honkongo panašumai, ypač dèl socialinių išlaidų, kaip reakcija ị kintančias demografines ir ekonomines aplinkybes (Abrahamson, 2017). Svarbu išanalizuoti ir palyginti šių Rytų Azijos valstybių igyvendintas reformas ir socialinès politikos principus, kurie išsamiai apžvelgti žemiau pateiktoje lentelejje.

Esminiai Rytų Azijos gerovès valstybių bruožai

\begin{tabular}{|l|l|}
\hline Honkongas & Parama teikiama tik vyresniems žmonėms, bedarbiams ir pažeidžiamoms \\
& grupėms \\
& Pensijos - iš privalomų kaupimo sistemų \\
& Nevyriausybinių organizacijų švietimo ir socialinių paslaugų teikimas \\
& Universalios sveikatos apsaugos paslaugos
\end{tabular}


RYTŲ IR PIETRYČIŲ AZIJOS GEROVĖS VALSTYBIŲ MODELIŲ SPECIFIKA...

\begin{tabular}{|l|l|}
\hline Japonija & $\begin{array}{l}\text { Nacionalinė socialinio draudimo sistema pensijoms ir sveikatos priežiū- } \\
\text { rai, kartu su papildomu imonių draudimu } \\
\text { Marginalinis (likutinis) valstybės gerovės užtikrinimas } \\
\text { Privataus paslaugų sektoriaus skatinimas, nors pajamų nepakankamumo } \\
\text { atvejais egzistuoja ir viešoji paramos sistema }\end{array}$ \\
\hline Singapūras & $\begin{array}{l}\text { Privalomo valstybinio kaupiamojo Centrinio aprūpinimo fondo vaidmuo } \\
\text { senatvès, būsto aprūpinimo, sveikatos apsaugos ir švietimo išlaidų atve- } \\
\text { jais } \\
\text { Tikslinè šeimos ir bendruomenės teikiama gerovės parama } \\
\text { Nevyriausybinio sektoriaus vaidmuo užtikrinant valstybės skatinamą } \\
\text { gerovę }\end{array}$ \\
\hline $\begin{array}{l}\text { Korèjos } \\
\text { Respublika }\end{array}$ & $\begin{array}{l}\text { Nacionalinės sveikatos apsaugos ir nacionalinių pensijų draudimo siste- } \\
\text { ma } \\
\text { Vyriausybės teikiama gerovės parama neturto ir nedarbo atvejais }\end{array}$ \\
\hline Taivanas & $\begin{array}{l}\text { Nacionalinė sveikatos ir nedarbo draudimo sistema } \\
\text { Pensijų priklausymas nuo darbo rinkos } \\
\text { Ribotos vietinės valdžios teikiamos gerovès paslaugos } \\
\text { Pagrindinis vaidmuo teikiamas šeimai }\end{array}$ \\
\hline
\end{tabular}

Šaltinis: sudaryta autorių, remiantis A. Walker'iu, C. K. Wong’u (Karim ir kt., 2010)

Nepaisant tam tikrų socialinių pasiekimų, Rytų Azijos gerovès valstybių modeliai neišvengia ir kritikos. Remdamasis R. Goodman'o ir G. White'o atliktais tyrimais, H. Kwon'as akcentuoja, kad ,svarbus šeimos vaidmens akcentavimas lemia rimtas santykių tarp lyčių ir moterų padèties pasekmes. Modelis labai stipriai remiasi moterimis, kaip svarbiausiomis paramos teikejjomis, o tai, kartu su moterų dalyvavimu darbo rinkoje, labai didina joms tenkantị krūvị"“ (Kwon, 1999, p. 233). Tokios gerovès sistemos skatina socialinę-ekonominę nelygybę. Silpnesni, pažeidžiami, neturtingi asmenys šiose sistemose stigmatizuojami. Gerovès politika minimose šalyse atskleide konservatyvaus dominavimo politinę logiką ir / arba autoritarines institucijas, kurios buvo įkurtos ant šio pagrindo ir juo rèmėsi.

P. Saunders'as ir A. J. He 2019 metais pasirodžiusioje monografijoje ,,Socialinè apsauga Rytų Azijos visuomenèse. Iššūkiai, atsakymai ir įtakos“ pateikè ịvairių socialinės apsaugos aspektų analizę kiniškose Rytų Azijos visuomenėse Kinijoje, Taivane ir Honkonge. Autoriai aptarè trūkumus ir kylančias socialinès politikos problemas, apžvelgè esamų programų efektyvumą. Šioje monografijoje aptarti tokie socialinei politikai Rytų Azijoje tenkantys iššūkiai, kaip skurdas, atskirtis, nelygybė, stigma, globos, maisto stoka ir prasta jo kokybė, kaimo izoliacija ir nepriežiūra, šeimų konfliktų dinamika ir vaikų nepriežiūra. Regiono valdžia pripažįsta, kad socialinè apsauga turi būti ,taiklesné“ ir labiau atliepti marginalinių grupių interesus (Sounders, He, 2019). 
Apibendrinus galima teigti, kad Rytų ir Pietryčių Azijos gerovės programoms būdingi socialinio draudimo principai, valstybès atlieka reguliuotojos vaidmenị, socialinių programų aprèptis pamažu didinama, pastebima didelè priklausomybė nuo šeimos, konfucianizmo įtaka. Rytų Azijos valstybės gerovès programas sukūrè ne siekdamos socialinio-ekonominio perskirstymo, bet ekonomikos vystymosi ir politinio legitimumo. Nors visiško konsensuso čia nèra, tam tikras susitarimas akademinèje bendruomenèje visgi egzistuoja, kad Azijos, ypač Rytų, valstybès skiriasi nuo Vakarų šalių, tad turètų kurti savitą ar net kelis savitus gerovès valstybių modelius.

\section{Išvados}

1. Atlikdami Rytų ir Pietryčių Azijos gerovès valstybių, jų raidos tyrimus daugelis tyrëjų rèmėsi G. Esping-Andersen'o gerovès režimų metodologija. İrodyta, kad Rytų ir Pietryčių Azijos valstybės turi liberaliojo ar konservatyviojo režimų bruožų. Kartu šios valstybės pasižymi unikaliais, išskirtiniais, tik šiam regionui būdingais bruožais, tad, nors visiško konsensuso nepasiekta, galima pastebèti, kad mokslininkai visgi sutaria, jog Rytų ir Pietryčių Azijos regioną teisinga vertinti ir analizuoti kaip paskirą trijų gerovės modelių tipologiją išplečianti gerovès valstybės modeli (ar modelius).

2. Rytų ir Pietryčių Azijos gerovès valstybèms būdinga konfucianizmo ịtaka, paternalizmas, stiprūs šeimyniniai ryšiai, išskirtinis šeimos vaidmuo socialinès rūpybos srityje, be to, produktyvizmas, ekonominio augimo siekis, ekonominių tikslų pirmenybe socialinių (gerovès) tikslų atžvilgiu, mažos socialinès išlaidos ir kt. Gerovès valstybès kūrimas čia glaudžiai susijęs su specifine politinio valdymo sistema, visuomenès socialine sandara ir unikalia kultūra.

3. Rytų ir Pietryčių Azijos gerovès valstybės modelis kritikuojamas dèl nelygių santykių tarp lyčių ir dèl moterų padèties, taip pat dèl socialinès-ekonominès nelygybès skatinimo kitais požiūriais, socialinių paslaugų šiose valstybėse kokybès bei jų trūkumo.

\section{Literatūra}

Abrahamson, P. (2017). East Asian welfare regime: obsolete ideal-type or diversified reality. Journal of Asian Public Policy, Vol. 10(1), p. 90-103.

Chiavacci, D., Grano, S. (2020). A New Era of Civil Society and State in East Asian Democracies. In D. Chiavacci, S. Grano, J. Obinger (eds.). Civil Society and the State in Democratic East Asia. Between Entanglement and Contention in Post High Growth. Amsterdam: Amsterdam University Press.

Choi, Y. (2007). A New Theoretical Idea of East Asian Welfare Regimes. Barnett Papers in Social Research, Vol. 3, p. 1-26. 


\section{RYTŲ IR PIETRYČIŲ AZIJOS GEROVĖS VALSTYBIŲ MODELIŲ SPECIFIKA...}

Choi, Y. (2012). End of the Era of Productivist Welfare Capitalism? Diverging Welfare Regimes in East Asia. Asian Journal of Social Science, Vol. 40(3), p. 275-294.

Esping-Andersen, G. (1990). The Three Worlds of Welfare Capitalism. Princeton: Princeton University Press.

Goodman, R., White, G., Kwon, H. (1998). The East Asian Welfare Model-Welfare Orientalism and the State. London: Routledge.

Holliday, I. (2000). Productivist Welfare Capitalism: Social Policy in East Asia. Political Studies, Vol. 48(4), p. 706-723.

Hort, S. E., Kuhnle, S. (2000). The coming of East and South-East Asian welfare states. Journal of European Social Policy, Vol. 10(2), p. 162-184.

Yang, N. (2017). East Asia in transition: re-examining the East Asian welfare model using fuzzy sets. Journal of Asian Public Policy, Vol. 10(1), p. 104-120.

Yeh, C. Y., Ku, Y. W. (2021). Welfare attitude and economic developmentalism in new democratic developmental welfare state: an examination of the Taiwanese case. Journal of Asian Public Policy, Vol. 14(1), p. 13-29.

Izuhara, M. (2013). Handbook on East Asian Social Policy. Cheltenham: Edward Elgar Publishing.

Karim, S. A., Eikemob, T. A., Bambra, C. (2010). Welfare state regimes and population health: Integrating the East Asian welfare states. Health Policy, Vol. 94(1), p. 45-53.

Kim, S. (2019). Reappraisal of the Developmental Welfare State Theory on the Underdevelopment of State Welfare in East Asian Growth Economies: The Case of South Korea. Journal of Asian and African Studies, Vol. 55(4), p. 568-585.

Kim, W. S., Shi, S. J. (2013). Emergence of New Welfare States in East Asia? Domestic Social Changes and the Impact of "Welfare Internationalism" in South Korea and Taiwan (1945-2012). The International Journal of Social Quality, Vol. 3(2), p. 106-124.

Köhler, G. (2014). Is There an Asian Welfare State Model? East and South Asian Trajectorie and Approches to the Welfare State. Prieiga internete: http://library.fes.de/pdf-files/iez/10619.pdf

Kwon, H. (1999). East Asian Welfare States in Transition Challenges and Opportunities. IDS Bulletin, Vol. 30(4), p. $229-250$.

Kwon, H. (2007). Transforming the developmental welfare states in East Asia. Economic \& Social Affairs, Vol. 40, p. 1-15.

Lin, K., Chan, R. K. H. (2013). Repositioning three models of social policy with reference to East Asian welfare systems. International Social Work, Vol. 58(6), p. 831-839.

Miyamoto, T. (2003). Dynamics of the Japanese Welfare State in Comparative Perspective: Between 'Three Worlds' and the Developmental State. The Japanese Journal of Social Security Policy, Vol. 2(2), p. 12-24.

Mok, K. H., Kühner, S., Yeates, N. (2017). Introduction - Managing Welfare Expectations and Social Change: Policy Responses in Asia. Social policy and administration, Vol. 51(6), p. 845-856.

Park, Ch. (2007). he Divergent Paths of the East Asian Welfare Regimes: The Effects of Production Regimes and Democratization. Korean Social Science Journal, Vol. 1, p. 39-70.

Park, Ch., Jung, D. (2007). The Asian Welfare Regimes Revisited: The Preliminary Typologies Based on Welfare Legislation and Expenditure. Prieiga internete: https://pdfs.semanticscholar.org/0bd3/935a19ce563a8af2c0a 99b92fa01977ae18c.pdf?.ga=2.265718 671.1284000469.1598606984-377402895.1585566906

Saunders, P., He, A. J. (2019). Social Protection in East Asian Chinese Societies. Challenges, Responses and Impacts. London: Routledge.

\section{CHARACTERISTICS AND DEVELOPMENT PROBLEMS OF WELFARE STATE MODELS IN EAST AND SOUTHEAST ASIA}

\section{Adomas Vincas Rakšnys, Giedrè Svirbutaitė-Krutkienė, Arvydas Guogis}

\section{Summary}

For a long time, social policy in East and Southeast Asia has received no attention, either inside or outside the region. Previous studies and research have 
understood and examined the welfare states of East and Southeast Asia exclusively through the economic factor, in particular, the economic crisis that hit Asia as a whole in 1997, and its impact has led scholars and practitioners to discuss how East Asian states have coped with such a rapid socio-economic crisis, and how such experiences have or have not been transformed into welfare programmes. In contrast to economic growth, social welfare has long been completely forgotten in East and Southeast Asian countries. Economic development has been a key objective of East and Southeast Asian states, and welfare state programmes and social policy itself have been a tool to achieve this goal, and have often acted as if in the shadow of the periphery of economic policies.

However, when the Danish sociologist G. Esping-Andersen introduced the classification of welfare models and the subsequent methodology in 1990, it also aroused interest in the programmes of welfare states in East and Southeast Asia and their classification. In analysing the welfare regimes of East Asia, some authors took up the framework of G. Esping-Andersen's theory of welfare regimes, while other authors were convinced that the welfare regimes specific to the East and Southeast Asia region constitute a separate model that has expanded the classification presented by Esping-Andersen. To achieve the aim of modelling the regimes (welfare states), the following tasks were set: 1) to review welfare state models of East and Southeast Asia and their development; and 2) to single out the characteristics of the welfare states of East and Southeast Asia. The article is of the scientific review type: in pursuing the aim of revealing phenomena of the East and Southeast Asia emerging welfare state model, the authors use methods of the analysis of scientific literature, expert evaluation, synthesis, and descriptive and comparative analysis. This article presents the most important older and the most recent scientific works and research that analyse the welfare state models in East and Southeast Asia, their development and their main features. It is important to point out to readers that in the study of welfare states and their development in East and Southeast Asia, many authors have adopted the methodology of G. EspingAndersen's welfare regimes: East and Southeast Asian states have been shown to have the characteristics of liberal or conservative regimes. However, these countries have unique, distinctive features specific to this region; therefore, although there is no strong consensus here, it can be observed that there is still some agreement among scholars that it is fair to view and analyse the East and Southeast Asia region as a separate welfare state model (or models) that expands the typology of the three welfare models.

The article proves that the welfare state of East and Southeast Asia is characterised by the influence of Confucianism, paternalism, strong family ties, and the important role of the family in social welfare, productivity, economic growth, the 
RYTŲ IR PIETRYČIŲ AZIJOS GEROVĖS VALSTYBIŲ MODELIŲ SPECIFIKA...

prioritisation of economic goals over social (welfare) goals, low social costs, etc. The creation of the welfare state is closely linked here to the system of specific political governance, the social structure of society, and the unique culture. However, the welfare state model in East and Southeast Asia is criticised for its gender inequality and the situation of women, as well as for promoting socio-economic inequalities in other ways, and for the quality and lack of social services in those countries.

Adomas Vincas Rakšnys - docentas, daktaras (socialiniai mokslai - vadyba), Kazimiero Simonavičiaus universiteto Verslo mokykla, Vilniaus kolegijos Verslo inovacijų katedra.

El.paštas: e_cnv@yahoo.com 